\title{
The case study of the big Latvian energy companies' compliance with the principles of sustainable development
}

\author{
Raja Kočanova, Ineta Geipele, Kārlis Ketners \\ Faculty of Engineering Economics and Management \\ Riga Technical University \\ Riga, Latvia \\ ineta.geipele@rtu.lv, raja.kocanova@latvenergo.lv,karlis.ketners@rtu.lv \\ Received: May 15, 2019. Revised: June 12, 2021. Accepted: September 27, 2021. Published: November $25,2021$.
}

\begin{abstract}
The rationale of the study is connected with the fact that society has increasingly begun to discuss its responsibility to the generation to come. Without economic aspects, social and environmental issues have become increasingly apparent because there is more and more relevant question whether the natural system will be able to withstand the increasing loading associated with human activities.

In Latvia there have been made attempts to promote the principle of sustainable development, its adoption and implementation. On the basis of the above stated rationale of the subject, the objective of the study is to estimate the big Latvian energy companies' compliance with the principles of sustainable development.

The reduction of energy sources and their capacity, greenhouse gas emission caused by energy production, and features of the energy market put forward branch enterprises in front of the principle of sustainable development and the idea of its implementation. To determine the big Latvian energy companies' contribution to sustainable development, in the survey of representatives of the business environment there have been included questions about the big Latvian energy companies' compliance with the principles of sustainable development. In the research paper there have been used the statistical analysis of data and the processing method.
\end{abstract}

Keywords - sustainable development; business activity in energy companies; principle of sustainable development; economic sustainability; social sustainability; environmental sustainability

\section{INTRODUCTION}

The 21 st century is characterised by significant change in the situation, but organisations have to operate in such a way to take advantage of the changes and move with changes into the external environment. The new era has also created new preconditions to the economy. The new economy is based on knowledge and modern technologies which have become the basis for the whole modern society. The new business activity takes place in cyberspace, and that space is the electronic intermediator which is not related to the geographic market. Under these circumstances, there are changes both in businesses, human perception and public liaison.
The rationale of the study is connected with the fact that at the end of the 20th century society increasingly began to discuss its responsibility to the generation to come. In addition to the economic aspects, social and environmental issues have become increasingly apparent because there is more and more relevant question whether the natural system will be able to withstand the increasing loading associated with human activities.

To comply with the principle of equity and enable to meet future generation needs, today it is urgent to understand what form of the next generation interests should be taken into account so that there could be welfare in the future.

In Latvia there have been made first attempts to promote the principle of sustainable development, its adoption and implementation. There have been developed different policy documents which include the principles of sustainable development. Solutions to environmental problems are also included in other policy plans, strategies and regulations.

Both worldwide and in Latvia there are enough general nature studies on sustainable development as an economic category (The following studies have been undertaken in Latvia: the Latvian energy policy, Towards a sustainable and transparent energy sector, Riga city Sustainable Energy Action Plan for 2010 - 2020, the Latvian strategy for sustainable development till 2030), but the questions about how to improve and develop the strategic management and to ensure sustainable development have not been answered.

On the basis of the above stated rationale of the subject, the objective of the study is to estimate the big Latvian energy companies' compliance with the principles of sustainable development.

The target of the study is large enterprises whose number of employees is above 250 .

On the theoretical and methodological basis of the study there are literature, scientific articles, publications issued in the USA, the European Union and in other countries, and Internet resources. The theoretical foundation of sustainable development concept, its nature, role and structure has been created using conclusions of the following scientists: 
J.Forrester, L.Meadows, H.Daly, S.Brunel, R.Schubert, E.Weizsäcker, A.Hasna, M.Weisheimer and etc.

The research methods. In the process of the research work there were being used common economic scientific quantitative and qualitative data analysis methods including various methods of analysis for studying the elements of the problem and the integrated parts of the process for later synthesising interconnections or defining laws, induction and deduction methods, mathematical modelling and statistical data processing techniques. The authors used large and medium-sized business leaders and specialists survey. The interpretation of the results includes the analysis of the questions in the questionnaire as well as the main conclusions based on the information obtained from the research.

\section{THEORETICAL AND METHODOLOGICAL FRAMEWORK}

In Latvia there have been made attempts to promote the principle of sustainable development, its adoption and implementation. In 2010 by calling of the Employers' Confederation, which represents businesses and United Nations Global Compact Latvian national network, together with the Latvian Confederation of Free Trade Unions, which represents employees, the Ministry of Justice, the Ministry of Welfare, the Ministry of Environmental Protection and Regional Development, the Saeima, the State Labour Inspectorate and the Corruption Prevention and Combating Bureau, which together represent the Latvian state, and the World Wildlife Fund, the Society for transparency „Delna”, the Society „Latvian association for Quality”, the Latvian Association of Personnel Management, the Latvian Association of Public Relations Professionals, the Latvian Advertising Association, the Latvian Association of Press Publishers, which together represent non-governmental organizations, created the Platform on Corporate Accountability and defined their understanding of social responsibility principles by the joint memorandum.

In the document there are indicated the main definition, priorities, generally defined relationship with the stakeholders and provision of information to the public. But specific companies which are the key enablers of the principle of sustainable development and social responsibility have not been engaged in the formulation of the document.

In Latvia there have been developed different policy documents which include the principles of sustainable development. Solutions to environmental protection problems are also included in other policy plans, strategies and regulations.

Compliance with the principles of sustainable development and their demonstration have become the necessity for enterprises operating or intending to operate on the international market, exporting products or making investments abroad, as well as for all who are interested in raising new investments and increasing competitiveness.

The reduction of energy sources and their capacity, greenhouse gas emission caused by energy production, and features of the energy market put forward branch enterprises in front of the principle of sustainable development and the idea of its implementation. If in consequence of energy production harm is done to the environment, the human suffers as the main stakeholder.

From the point of view of social responsibility the energy sector is the most essential. Compliance with the principles of sustainable development and their demonstration have become the necessity for enterprises operating or intending to operate on the international market, exporting products or making investments abroad, as well as for all who are interested in raising new investments and increasing competitiveness.

In the 70 s of the 20th century by the offer of the Club of Rome J.Forrester [1, 167] carried out the research, as a result of which it was stated that the future human development in the Earth limited physical space would have led to ecological disaster by the 20 s of the following century.

In turn, environmental science researchers L.Meadows [2, 119] and H.Daly [3, 43] introduced the concept of ,the economy in the balanced position", but to describe the economy which was in the balance with "the main environmental systems"; there was used the term sustainability [4, 30].

In 1984, works in that direction were combined within the World Commission on Environment and Development (the chairwoman of so called the „Brundtland Commission” was Prime Minister of Norway G.H.Brundtland), who offered the concept of sustainable development [5].

Broadly defined the sustainable development strategy is aimed at achieving harmony in relations between society and nature. According to the definition of the Commission sustainable development is ,the ability to meet the needs of the present while contributing to the future generations' needs" [5].

\section{DATA AND RESULTS}

To determine the Latvian big energy companies' contribution to sustainable development, the authors conducted the survey of business representatives. The survey included questions about the Latvian largest energy sector companies', i.e. JSC Latvenergo, JSC Latvijas Gäze and JSC Rigas Siltums, compliance with the principles of sustainable development. 


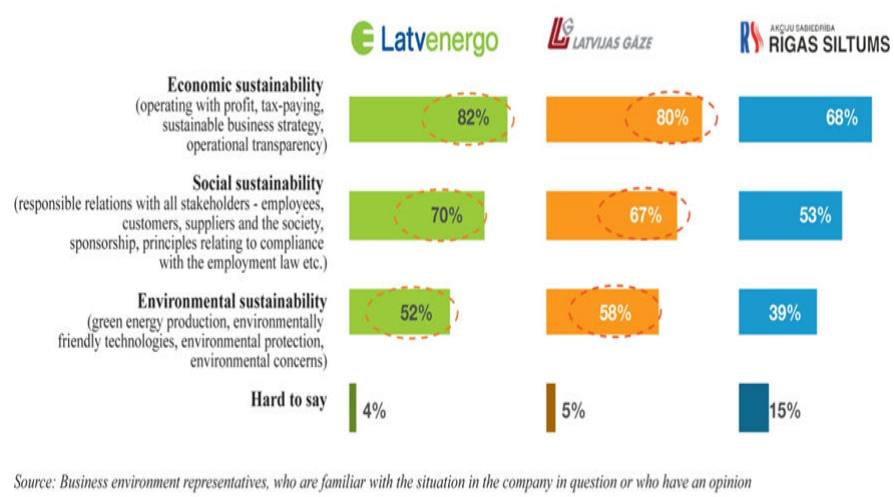

Fig. 1. Applicability of social responsibility aspects in large energy enterprises of Latvia

In the assessment of business environment representatives all three enterprises JSC Latvenergo, JSC Latvijas Gāze and JSC Rigas Siltums mostly comply with different aspects of economic sustainability. However, in the respondents' assessment JSC Latvenergo and JSC Latvijas Gãze comply with these aspects relatively more than JSC Rigas Siltums. In the same way more than half of polled business managers and owners have mentioned that all three companies JSC Latvenergo, JSC Latvijas Gāze and JSC Rìgas Siltums comply with social aspects of sustainability. Nevertheless, in the respondents' assessment JSC Latvenergo (70\%) and JSC Latvijas Gāze (67\%) comply with these aspects relatively more than JSC Rīgas Siltums (39\%). Respectively 52\%, 58\% and $39 \%$ business environment representatives have indicated that JSC Latvenergo, JSC Latvijas Gāze and JSC Rīgas Siltums comply with the environmental aspects of sustainability. Relatively least in the respondents' assessment JSC Rigas Siltums comply with this aspect but relatively more JSC Latvijas Gāze does.

Thinking about compliance of electricity, gas and heating supply companies with different aspects of sustainable development, JSC Latvenergo complies with environmental sustainability aspects mostly according to business managers and owners whose companies' annual turnover is over 7 million lats. In its turn JSC Latvijas Gāze complies with social aspects of sustainability more frequently according to the respondents who represent companies with turnover up to 100 000 lats. About JSC Rīgas Siltums social aspects of compliance with sustainability, on average, there are more confident business representatives who represent companies with turnover over 7 million lats.

There is the tendency that JSC Latvenergo complies with the environmental aspects of sustainability relatively more frequently according to managers and owners of mediumsized and large enterprises (50 or more employees).

About JSC Rīgas Siltums social aspects of compliance with sustainability relatively more frequently, on average, there are confident managers and owners of medium-sized and large enterprises (50 or more employees) (see Table 1.)
TABLE 1. THE COMPANIES' COMPLIANCE WITH THE PRINCIPLES OF SUSTAINABLE DEVELOPMENT: DIVISION BY NUMBER OF EMPLOYEES

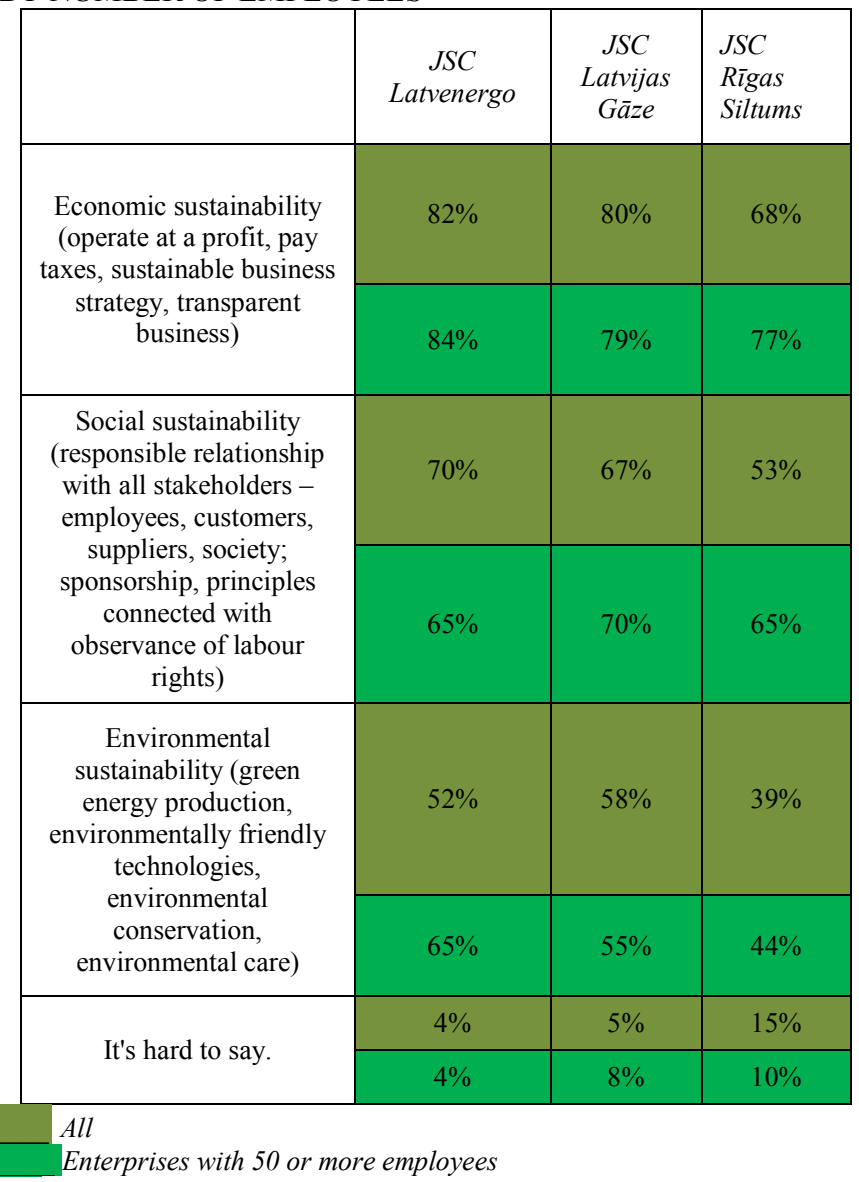

The base: Business environment representatives who know and have an opinion of the company

JSC Latvenergo: all, $n=254$; Enterprises with 50 or more employees, $n=37$

JSC Latvijas Gāze: all, $n=254$; Enterprises with 50 or more employees, $n=38$

JSC Rīgas Siltums: all, $n=256$; Enterprises with 50 or more employees, $n=49$

The data obtained gives the opportunity to judge that the Latvian business environment representatives are generally aware of the main principles of sustainable development and of the big energy companies' practice in the field of sustainable development. However, both the research data and other information on the companies have shown that currently in Latvia there are not science-based company ethical and sustainable development management techniques and systems of practical implementation. It is the authors' opinion that it is necessary and possible to develop these techniques and systems on the basis of the conditions of the main international standards providing the major priorities, i.e. mutual interest and benefit of business and society.

The concept of sustainable development is directly linked with the principles of social responsibility. All companies as legal persons receive „business licenses” from society receiving also rights and liabilities under the laws and 
regulations. Liberalisation and globalisation affect companies' expansion of operations that allows them to significantly increase their impact on society.

The authors characterise social responsibility as a contemporary pragmatic business strategic management element by the following basic factors:

- business top targets in the social context are sustainable development and appreciation in the market value. In this case the social function is minimally realized creating tangible and intangible assets, maintaining or increasing the number of jobs, realising fair business practices specified in the legislation;

- a stable trend in the world: to expand business social function over the statutory minimum obligations. The social responsibility programme implementation, enhancement of corporate management quality, congruence of interests with other members of social dialogue are considered as important strategy development elements;

- impact and pressure from the outside by increasing internal and external group role in enterprise performance (owners, shareholders, partners, staff, public at large, consumers, public institutions, the media and etc.) as well as the influence of competitors' initiative;

- usage of the international standards, rules (the code of conduct) and mechanisms, as well as methodical implementation guidelines and practical procedures of social and ethical programmes in business processes;

- the social and ethical principles-based business development strategy provides a good reputation, a high market value, extends the availability of additional capital, increases the impact of negotiations in relations with the state and society. Interaction and impact of these factors are shown in Figure 2.

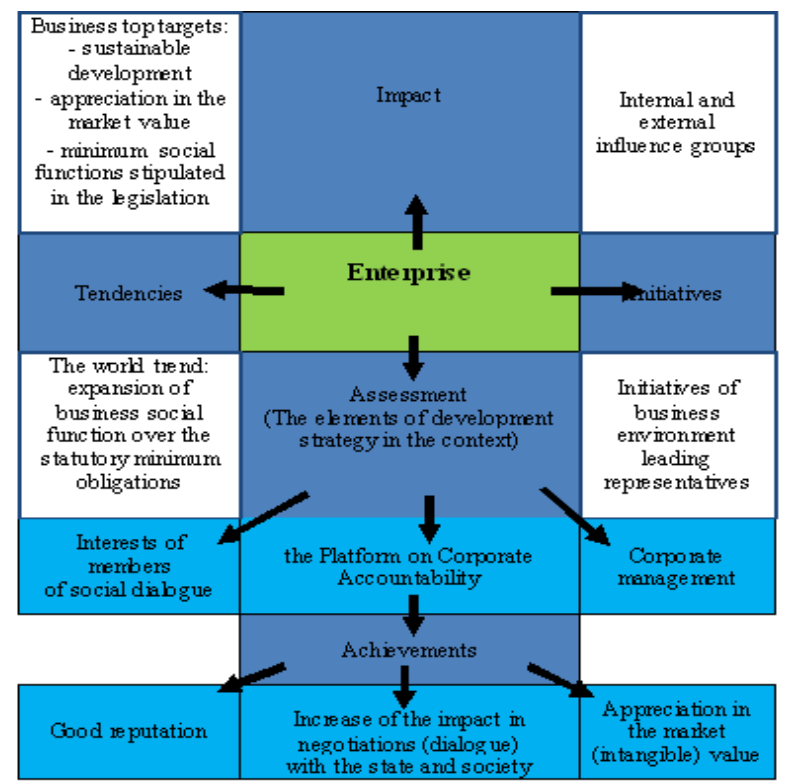

Fig. 2. Impact of the factors [Developed by the authors using $6 ; 7]$
The authors examined the possible business patterns of behaviour in relation to the Social Responsibility matrix form (see Figure 3).

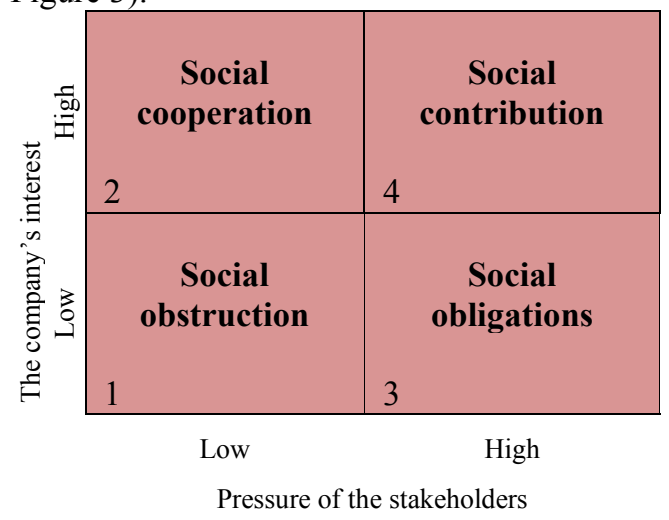

Fig. 3. The Social Responsibility matrix of strategical management [Developed by the authors using 6; 7]

In the situation of social obstruction companies do as little as possible for solutions of social and environmental problems. When there is exceeded the legal or ethical limit which separates acceptable from unacceptable practice, a typical reaction of the company is a denial and concealment of its actions. This model is ,indifferent”, and its supporters try to redirect financial flows to the centre. Instead of paying duties into regional and local budgets they «drain small towns dry» without caring about prospects.

Social cooperation strategy is adopted by a company which both complies with legal and ethical requirements and exceeds these requirements. The company may on a voluntary basis agree to take part in social programmes, but it has to be convinced that these programmes are worth supporting. Someone has to reach out to the company because it will not show the initiative in searching possibilities. The supporters of this model, e.g. large organisations, however, practise a strategic approach to social responsibility. Social programmes are considered as business projects, and in accordance with this approach management is conducted: costs are minimized, efficiency is required, and selection of initiatives is competitive. Sometimes companies can help municipal administrations to plan budgets or accept municipal managers for practical training.

Social obligations strategy includes organisational activities directed only to compliance with legislation. Managers of such organizations are convinced that the primary task is to make profits. Their behavioural strategy is cooperation with non-commercial organisations and funds in the field of social projects. This model determines the organization's low interest, but the pressure of the stakeholders is great. The company's interest is low, therefore it endeavours to shift activities in the field of social responsibility on nonprofit/non-governmental organisations avoiding development, planning and implementation of the principle of social responsibility; it confines itself to funds transfer to nonprofit/non-governmental organisations, on the pretext that these organisations can properly deal with money resources obtained. 
Social contribution is the strategy chosen by organizations determined to implement the main social responsibility requirements. These organizations cast themselves as public citizens and show the initiative to contribute for the public good. This model is socially oriented management concept. If only five years ago companies gave priority to „customer care" and ,increase of dividends to shareholders", today the most important thing is ,credibility” and , the highest ethical standards compliance". The main things are implementation of future visions, formation of leadership team, social problem solving and etc., confirmed by the fact that modern strategic management from the total quality management concept (TQM) is changing to total responsibility management concept (TRM), which requires greater attention to the requirements of various stakeholders and environmental issues.

In strategic management problems of social responsibility principles and requirements implementation are solved at corporate and public levels. At the corporate level by acting in accordance with the codes of ethics, increasing information transparency and creating a dialogue with the stakeholders there is obtained improvement of the strategic management quality, which contributes to increasing stock market value of a company. At the public level there are used initiatives and standards (nonfinancial corporate social responsibility reports, social audit and consolidated ethical programmes) which contribute to the recognition of the company's social role. Today social responsibility reporting is not just the tool of image and reputation improvement and the annex to financial statements; in assessment of the company's activity increasing attention is paid to social responsibility of business, which is a tool for sustainable development implementation and a new element of strategic management.

At the international level there are various contracts, agreements and conventions, but there is no code of international rules to regulate business and its impact on society, therefore, according to UNCTAD (United Nations conference on trade and development) „... the increased power of corporations must be balanced by a sense of ethical business practices." [5].

In the energy sector the current economic development model is not sustainable in the long-term perspective as leads to the depletion of natural resources, causes loss and does harm to society. As discussed, sustainable development is the ability to meet the needs of the present while contributing to the future generations' needs. The concept of sustainable development is based on three main components: protection of the environment, provision of economic growth and ensuring social equality. Also many definitions of social responsibility determine companies' responsibility for compliance with social interests in the business strategy including ecological, economic and social aspects, and satisfaction of the public and other stakeholders expectations. Becoming a tool of sustainable development concept ensuring, social responsibility has to be observed in the strategic management of any sized companies.

\section{CONCLUSIONS}

The authors' results of the research have indicated that it is practically no strategic management element that could continue operating without improving, and the main changes are to be carried out in the strategic planning and implementation of the plan, but it requires a common approach.

To integrate sustainable development principles in the power industry, Latvia needs an active energy policy discussion both in relation to energy problems in general and the role of energy companies in the state system. The authors believe that, in view of the experience of Scandinavia and other foreign countries, in Latvia public attention should be focused on the split of priorities between the content of the energy policy and development of energy future quantitative indicators. The fair pricing mechanism is administered by the state; however, the national energy market participants are aware of the need to create a basis for the fair price mechanism that the problem of this mechanism in a long term perspective could be solved. Therefore, in strategic management there should be taken into account the need to solve a practical task such as creating a reasonable idea of the survival limit of activity and determination of strategic targets in energy provision, despite the fact that there is not known precise information for future development.

\section{REFERENCES}

[1] Дж Форрестер. Мировая динамика. М. Наука. 1978. - 384 c.

[2] D. Meadows, D.L. Meadows, J. Randers, W. Behrens The Limits to Growth. Universe books. New York. Universe Books. 1972. - 205 p.

[3] H.E. Daly Towards a Steady State Economy. San Francisco, W.H.Freeman. 1973. - 332 p.

[4] T. Schmitt, H. Trabert Kokospalmen am Nordseestrand. 100 heimliche Gewinner des Klimawandels. Ein Finanzbuch. - Frankfurter Allgemeine Buch. 2008. -240 p.

[5] Disclosure of the impact of corporations on society. Current trends and issues. Report by the UNCTAD secretariat [online]. [accessed 2010-0904] Accessible:

http://doc.mmu.ac.uk/aric/eae/Sustainability/Older/Brundtland Report.h tml www.unctad.org/en/docs/c2isar20_en.pdf

[6] G. Johnson, K.Scholes, R.Whittington Exploring Corporate Strategy, Pearson Education Limited, 2005. - 789 p.

[7] А.А.Томпсон-мл., А.Дж Стрикленд III. Стратегический менеджмент. Издательский дом «Вильямс». 2007. - 924 с.

\section{Creative Commons Attribution License 4.0 (Attribution 4.0 International, CC BY 4.0)}

This article is published under the terms of the Creative Commons Attribution License 4.0 https://creativecommons.org/licenses/by/4.0/deed.en_US 